\title{
Scientifically-methodical aspects of use of eroded lands in agricultural landscapes of zone of Forest-steppe
}

Kaminskyi V. ${ }^{1}$, Kolomiets L. ${ }^{2}$, Shevchenko I. ${ }^{3}$

NSC "Institute of agriculture of NAAS», Mashynobudivnykiv Str., 2, Chabany, 08162, Ukraine; e-mail: 1'iznaan@ukr.net, ${ }^{2,3}$ erosia-stop@ukr.net

The purpose. To analyze existing methods of optimization of land-use of village territories and to search ways of its rationalization from the point of view of a prospect of the further European integration of the state. Methods. System-structural analysis of approaches to optimization of land-use of village territories. Results. Scientifically-methodical fundamentals are brought of modern land-use on the basis of the integrated approach in management of intelligent use of agricultural lands by implementation of measures on protection, minimization and achievement of neutral level degradation processes, raise of efficiency of use of land-resource potential in erosion-hazardous agrolandscapes. Legal grounds, regional features of use of eroded lands are specified. Theoretical-and-methodological and applied aspects of optimization of land-use in view of multipurpose development of economy of village territories are developed. Conclusions. Main ways of optimization of land-use of village territories with implementation of innovative levers of their complex development are specified.

Key words: degradation of lands, lands of agricultural purpose, land-resource potential, conservation of lands, protection of lands, management of land resources.

\section{https://doi.org/10.31073/agrovisnyk201811-02}

Formation of an innovative model for the development of competitive agro-industrial production in Ukraine is impossible without the implementation of modern soil protection systems of agriculture and land-tenures, measures for the protection and rational use of earth of the agricultural setting that which will serve as a solid ground for applied mechanisms for reforming the domestic agricultural sector and the development of rural areas in the requirements of the European integration policy of Ukraine.

The search for ways to optimize agricultural land-tenures, effective forms of management of the functioning of natural-agricultural systems is an extremely urgent problem in the solution of which an important role belongs to:

- scientific support of measures for environmental and economic regulation of use of earth resource potential;

- development and implementation of the newest ground protection systems of agriculture as a mechanism of management the landed resources at the regional level in the context of the risks of environmentally safe agriculture.

Guard and rational use of agrolandscapes should become one of the priorities of the state policy in the agrarian sector, which determines the need to find ways to provide appropriate scientific support for a set of measures aimed at preserving fertility and stabilizing the ecological situation on erosion-hazard lands, increasing the productivity of agricultural sloping landscapes.

In Ukraine, the system of measures for the protection of earth of the agricultural setting, taking into account the influence of negative anthropogenic and natural factors, is not able to fully ensure the rational use, preservation and reproduction of the eroded agricultural lands of agricultural lands of sloping agrolandscapes.

Uncontrolled, anthropogenic loading on cultivated land leads to the active development of degradation processes, among which the processes of erosion and deflation of soils are the most damaging.

At the present stage, the functioning of the agrarian sector of the economy, the sharp leap in the manifestations of erosion processes is primarily due to the unbalanced structure of land-tenures of agrarian enterprises, a scientifically unjustified increase in the sown area of highly liquid agricultural crops such as sunflower, rape, maize for corn, other cultivated crops, large areas of sowing are also located on the sloping lands.

Thus, the current state of sloping agrolandscapes is characterized by a significant increase of soils of varying degree of blurriness, which requires the development of scientifically sound protection measures against degradation processes with a view of further ecology safe use of them, taking into account the requirements of sustainable land-tenures and agriculture. 
The theoretical and practical foundations of ecologically safe use of land resources in agrolandscapes are also being explored in Western European countries and US through the development of innovative methods for well-balanced use of agricultural lands in order to increase agricultural competitiveness, improve the state of the environment and develop rural areas $[1,2]$.

The purpose of research. To prevent the harmful effects of water erosion and deflation on the soil cover of sloping agricultural lands, based on the results of scientific activity and land management practices, to justify a comprehensive system of measures for the protection and rational use of the eroded soils in the earth of the agricultural setting, by removing them from intensive cultivation for the canning in the modern conditions of functioning of the agroindustrial the complex.

Methods of research - analysis, evaluation and planning of the structure of agricultural land-tenure based on the basis of ecological and landscape land management. Commonly accepted methods: experimental field observations and laboratory determinations, morphological comparisons and analogues, use of ecological-landscape axiomatics as a method of cognition, cartographic, balance, statistical and economic, calculation and constructive method of landscape modeling, instrumental determination of the intensity of water-erosion processes development.

Research results. One of the most negative consequences of the land reform was the land distribution of large areas of degraded and unproductive land without taking into account their ecological component of their use, in order to suspend processes of loss of soil fertility, deceleration of deflation and water erosion.

The last of these is the most significant factor in reducing land productivity and degradation of lands agrolandscapes.

The total area of agricultural lands affected by water erosion in agricultural land use is 13.3 million hectares (32\%), including 10.6 million hectares of arable land.

The structure of eroded lands is more than 4.5 million hectares with medium and strongly washed soils, including 68 thousand hectares, which completely lost the humus horizon.

In the world, the processes of water and wind erosion are the most dangerous among processes of degradation $-56 \%$ and $28 \%$ respectively [3,4].

One of the main factors that destabilizes the ecological situation in sloped agrolandscapes is unreasonable, environmentally and economically ill-considered agricultural development and cultivating the land, at the same time intensive use of large areas of eroded and erosion-sensitive lands are also involved. However, according to Article 7 of the Law of Ukraine " On the Procedure for Allocation of Land Plots in kind (in Places) to The Owners of Land Portions", a legislative provision is provided for exclusion from the area of land plots subject to distribution - degraded, unproductive, as well man-made contaminated agricultural land that needs to be canned. As a result, the ecological stability of agrolandscapes has been violated, since this property of agricultural territories depends to a large extent on natural phytocoenosis preserved within the agricultural landscape.

Thus, the improvement of the ecological situation of agricultural-developed areas, including the sloping lands, depends both on optimization of the structure of land-tenure of agricultural enterprises and on the reduction of plowed land of the state land fund due to the withdrawal from the intensive cultivation of degraded and unproductive arable land, expansion of the natural area forage lands and forest plantations, the restoration of the field protecting forest plantations and the creation of their additional ranges, that is depends on increasing the share of ecologically stabilizing lands. Such measures will provide optimal conditions for the formation of sustainable ecosystems, functioning on the principles of natural analogues that have anthropogenic regulative impact.

Today in Ukraine created a legal framework that regulates the use and protection of land, including the earth of the agricultural setting [5-7].

The Law of Ukraine "On the Protection of Land" defines the main priorities of the state in the field of land protection through the predominance of environmental safety requirements for the use of land as a spatial basis, natural resource and basic means of production, limiting the impact of economic activity on land resources, and others. [6].

Implementation of a system of measures for the removal of degraded, including eroded soils, agricultural lands for canning (maximum conservation of the object) in the present realities of agricultural production remains the main and extremely important direction in preserving and improving the fertility of eroded soils of sloping agrolandscapes.

Canning of lands is one of the cheapest, not requiring significant capital and material costs, measures to improve the fertility of eroded soils. 
Taking into account the current financial crisis of the majority of agricultural producers and the understanding that allocation of funds to increase and preserve the soil fertility from the state budget in the near future is not expected, this organizational and legal ecological stabilization measure is now becoming even more urgent.

Numerous publications of the scientific community in Ukraine show that the process of the canning of earth of the agricultural setting in the state is carried out at very slow pace. Among the reasons that slow down these processes, the most significant are the almost complete lack of legal and regulatory framework for the removal of degraded land for canning, clear economic and environmental criteria like norms of maximum permissible soil contamination, their qualitative status, optimal ratio of land, indicators of degradation of lands and soils.

In the opinion of the majority of scientists and practitioners of agricultural development, one of the initial stages of the canning of degraded soils in the earth of the agricultural setting should be monitoring of soils and lands, on the basis of which indicators will be able to establish the fact of deterioration of the characteristics of the soil cover of a particular land, and, accordingly, include a land plot to one of the varieties of land that can be canned[8, 9].

Thus, the NSC "Institute of Agriculture of NAAS", as one of the main scientific clusters of the National Academy of Agrarian Sciences, is working on the development of conceptual directions, scientific and practical recommendations for optimizing the use of Ukrainian land, the theoretical and practical foundations of modern agricultural systems for modern agroindustrial enterprises.

The scientists of the NSC "IA NAAS" established the basic principles of the landscape-ecological organization of the territory of land use, based on the application of the genetic-morphological method of structuring the territory in combination with the position-dynamic and paragenetic characteristics of the basin structures for substantiation and implementation of land management projects for the modern conservation measures, rational use and reproduction of the productive potential of erosion-hazardous lands.

The theoretical and methodological bases of formation of soil protection agricultural landscapes were substantiated on the principles of land-use planning and development of the main components of the soil protection adaptive-landscape system of agriculture for the contour-landscape organization of the territory and differentiated use of land within the limits of not only separate economic structures, but also catchment basins of small rivers and individual natural-territorial complexes.

The main measure taken in the process of drawing up and implementing this system is the optimization of the land-tenure structure by removing from intensive cultivated degraded lands, steep slopes, erosionally hazardous areas for their their afforestation or increasing areas of grassland.

For the successful implementation of the norms of the Law of Ukraine "On Land Management", in particular regarding land management in all categories of land irrespective of the forms of ownership and the regulation of existing land management facilities, the use of the landscape-ecological approach is also necessary. This concerns the identification of disturbed lands, lands affected by negative processes, scientific substantiation and carrying out of measures for restoration or canning, reclamation of disturbed lands, improve the quality of unproductive land, protection of land from erosion.

Taking into account the special role of earth of the agricultural setting in providing the population with food products, and industry as raw materials, the solution of these issues is possible only by implementing the work of land management and all required measures, in particular - the drawing up of working projects on land management regarding to the formation and implementation of a system of soil protection measures (soil protection against erosion ) by applying the main components of the adaptive-landscape system of agriculture with the contouring-reclamation organization of the territory; drafting of working projects on land management for canning of degraded and unproductive lands, reclamation of disturbed lands, culturallytechnical works, protection of land from erosion, flooding, increase and preservation of soil fertility.

NSC "Institute of Agriculture of NAAS" has considerable scientific and practical experience in the development of land management projects, and we are ready to provide services in the field of land management, as our scientific institution has all the permits that required for land management works.

The scientific centers of the NSC "Institute of Agriculture of NAAS" are developing conceptual provisions on the main criteria and indicators that determine the need for removal from the intensive processing of degraded, including eroded, unproductive and other lands. These provisions include legal grounds, regional features of the use of eroded lands, economic incentives for canning measures for degraded lands.

In the territory of the basic farm of land-tenure for the protection of soil from erosion NSC "Institute of Agriculture of NAAS" (Obukhiv district, Kyiv region, Right-Bank Forest-steppe) during the period of 
denationalization and privatization of the earth of the agricultural setting for agricultural enterprises, were taken measures to optimize the structure of erosion-hazardous agrolandscapes. At the same time, from intensive cultivation, about 400 hectares of eroded lands of varying degree of soil washout on slopes with a steepness of more than $3^{\circ}$ were removed. As a result, in the area of land-tenure of the agricultural enterprise the arable land area decreased from $91 \%$ to $60 \%$, and natural forage land increased from $8 \%$ to $39 \%$. These land plots were identified on the project plan of land-tenure and were attributed to lands of environmental protection purposes.

The results of the calculations show that the transfer of medium- and strongly-washed soils on steep slopes of more than $3-5^{\circ}$ (II and III agroecological groups of lands) for permanent canning (planting vegetation) provides almost twice reduction of soil losses from erosion in the land-tenure of the farm.

The conducted researches have showed that removal from intensive cultivation of sloping eroded lands and their transfer to forage lands under the vegetation planting caused a steady tendency to improve the water-physical indicators and characteristics of the nutritional regime of the leached typical chernozem of the studied morphological units of the agricultural landscape (Table).

1. Indicators of soil fertility depending on the way of using sloping lands and their canning period (Obukhiv district, Kyiv region)

\begin{tabular}{|c|c|c|c|c|c|c|c|}
\hline \multirow[b]{2}{*}{ Landscape } & \multirow[b]{2}{*}{ Type of soils } & \multirow[b]{2}{*}{$\begin{array}{l}\text { Method of } \\
\text { using sloping } \\
\text { lands }\end{array}$} & \multirow[b]{2}{*}{$\begin{array}{l}\text { Number } \\
\text { of years } \\
\text { of } \\
\text { planting } \\
\text { vegetati } \\
\text { on }\end{array}$} & \multirow[b]{2}{*}{$\begin{array}{l}\text { Angle } \\
\text { (degre } \\
\text { es) of } \\
\text { the } \\
\text { slope }\end{array}$} & \multirow{2}{*}{$\begin{array}{l}\text { Amount } \\
\text { of } \\
\text { waterpro } \\
\text { of } \\
\text { structura } \\
\text { I } \\
\text { fractions } \\
, \%\end{array}$} & \multicolumn{2}{|c|}{$\begin{array}{l}\text { Fertility } \\
\text { Indicators }\end{array}$} \\
\hline & & & & & & $\begin{array}{l}\text { Humus } \\
, \%\end{array}$ & $\mathrm{pH}$ \\
\hline “ Dachna” & $\begin{array}{l}\text { Typical } \\
\text { chornozems } \\
\text { light washed, } \\
\text { light loam }\end{array}$ & $\begin{array}{l}\text { Seeds of cereal } \\
\text { grasses }\end{array}$ & 5 & $3-4$ & 47,9 & 1,60 & 7,2 \\
\hline $\begin{array}{l}\text { "Kolomyj- } \\
\text { shhyna" }\end{array}$ & $\begin{array}{l}\text { Typical } \\
\text { chornozems } \\
\text { medium } \\
\text { washed, light } \\
\text { loam }\end{array}$ & $\begin{array}{l}\text { Self-healing of } \\
\text { vegetations }\end{array}$ & 7 & $5-6$ & 47,2 & 1,67 & 7,3 \\
\hline $\begin{array}{l}\text { "Xmaryni } \\
\text { verby" }\end{array}$ & $\begin{array}{l}\text { Typical } \\
\text { chornozems } \\
\text { strongly } \\
\text { washed, light } \\
\text { loam }\end{array}$ & Rehabilitation & 12 & $12-15$ & 40,9 & 1,79 & 7,1 \\
\hline "Yasynove" & $\begin{array}{l}\text { Typical } \\
\text { chornozems } \\
\text { strongly } \\
\text { washed, light } \\
\text { loam }\end{array}$ & Rehabilitation & 17 & $10-12$ & 56,8 & 1,83 & 7,1 \\
\hline $\begin{array}{l}\text { Herbal } \\
\text { drainage } \\
\text { (stationary } \\
\text { experiment) }\end{array}$ & $\begin{array}{l}\text { Typical } \\
\text { chornozems } \\
\text { medium } \\
\text { washed, light } \\
\text { loam }\end{array}$ & $\begin{array}{l}\text { Hayfield, } \\
\text { pasturage }\end{array}$ & 19 & $5-7$ & 55,6 & 1,76 & 6,9 \\
\hline “Lisok" & $\begin{array}{l}\text { Typical } \\
\text { chornozems } \\
\text { strongly } \\
\text { washed, light } \\
\text { loam }\end{array}$ & Pasturage & 23 & $7-10$ & 66,7 & 1,88 & 6,8 \\
\hline
\end{tabular}


With an increase in the period of planting vegetation on eroded lands from 5 to 23 years, the indexes of humus content and main macroelements of washed soils increased, their acidity was optimized.

Determination of the content of waterproof structural fractions, depending on the method of use and the duration of planting vegetation of sloped washed soils, showed that their content increases in proportion to the duration of the canning period.

It should also be noted that during the years of observation within the studied agrolandscapes no groundwashing was observed.

Removal from intensive cultivation for the canning of medium and strongly washed soils and their transfer to forage land allowed farms to intensify the use of fertile plain arable lands.

The expediency of removing sloping eroded lands from cultivation is also evidenced by the increase in the productivity of the main agricultural crops grown on the sloping lands, since most of the mineral and organic fertilizers that were used to maintain the appropriate fertility level of the soils of eroded sloping agrolandscapes apply on the slope cultivated arable land, thereby optimizing the fertilizer system of agricultural crops with intensive technologies for their growing [10-14].

Consequently, canning of sloped eroded lands can be perceive as an important organizational and legal measure for increasing and preserving the fertility of degraded soils of agricultural landscapes, and also provides optimization of agricultural land use by removing unsuitable for intensive economic use of land and transferring it to another category of land.

However, the experience gained shows that for the successful implementation of this measure, the Law of Ukraine "On Land Canning", the draft of which is under consideration in the Verkhovna Rada, should be adopted, as well as the development of a number of necessary measures to strengthen the protection of the current legislation, in particular, established by the Land Code of Ukraine and the Law of Ukraine "On the Protection of Land".

Taking into account the main provisions specified in the new edition of the "Basic Principles (Strategy) of the State Environmental Policy of Ukraine for the Period up to 2020", the NSC "IA NAAS" identified the modern approaches to the main directions of development of modern systems of land-tenure and agriculture, implementation of measures on protection and rational the use of earth of the agricultural setting, which should become the basis for forecasting the development trends of rural areas of the state in the medium and long-term prospective, in the context of the National Plan actions to combat land degradation and desertification (Order of the Cabinet of Ministers of Ukraine dated March 30, 2016, No. -71-p).

\section{Conclusions}

The withdrawal from the economic circulation of eroded soils of sloping agrarian landscapes in the earth of the agricultural setting for a certain period of time for the implementation of measures for the restoration of fertility and the provision of an environmentally satisfactory state of soils should be considered as a system of agroecological, organizational, economic and regulatory measures.

The structural components of the identified canning measures for eroded lands are considered in combination and interconnection, however, they retain their individual significance.

An analysis of the practice of the canning of lands measures suggests that in the agroecological sense, this measure provides a significant reduction in soil losses in case of using these lands for development of fodder production (hayfields, pastures) and contributes to the increase of fertility rates of washed soils, improves the ecological state of the environment as a whole.

\section{Bibliography}

1. Ben R. Martin. (2002). Technology foresight in a rapidly in a globalizing. International Practice in Technology Foresight. Vienna: UNIGO. P. 14.

2. Bishop P., Hines A. (2007). Thinking about the Future, Guideline s for Strategic Foresights. Social Technologies. Washington. $98 \mathrm{p}$.

3. Hazarika M., Honda H. (2001). Estimation of Soil Erosion using Remote Sensing and GIS. Its Valuation \& Economic Implications on Agricultural Productions. The 10th International Soil Conservation Organization Meeting at Purdue University and the USDA-ARS Soil Erosion Research Laboratory. P. 1090-1091.

4. Morgan R.P.C. (2005). Soil Erosion and Conservation. Oxford: Blackwell Publishing. 304 p.

5. Zakon Ukrainy «Pro zemleustrii»: pryiniatyi 22.05.2003 r. No 858-IV. Vidom. Verkhov. Rady Ukrainy (VVR). 2003. No 36. St. 282. [The law of Ukraine "On land management" adopted 22.05.2003 No. 858-IV. VDOM. Ver. Rada of Ukraine (VVR). 2003. No 36. St. 282]. [In Ukrainian]. 
6. Zakon Ukrainy «Pro okhoronu zemel»: pryiniatyi 19.06.2003 r. No 962-IV. Vidom. Verkhovnoi Rady Ukrainy (VVR). 2003. No 39. St. 349. [Law of Ukraine "On the Protection of Land": adopted on June 19, 2003 No. 962-IV. Wow The Verkhovna Rada of Ukraine (BP). 2003. No. 39. Art. 349]. [In Ukrainian].

7. Zakon Ukrainy «Pro Osnovni zasady (stratehiiu) derzhavnoi ekolohichnoi polityky Ukrainy na period do 2020 roku»: pryiniatyi 21 hrudnia 2010 r. No 2818-VI. Vidom. Verkhovnoi Rady Ukrainy (VVR). 2011. No 26. St. 218. [The Law of Ukraine "On the Basic Principles (Strategy) of the State Environmental Policy of Ukraine for the Period up to 2020": Adopted December 21, 2010 No. 2818-VI. Wow The Verkhovna Rada of Ukraine (BP). 2011. No 26. Art. 218]. [In Ukrainian].

8. Kanash O.P., Kofman I.la. (1998). Konservatsiia dehradovanykh i maloproduktyvnykh zemel yak systema zakhodiv $z$ renaturalizatsii dovkillia. [Conservation of degraded and unproductive land as a system of measures for the re-naturalization of the environment]. Ahrokhimiia i gruntoznavstvo. Spets. vyp. 4.2. P. 10-12. [In Ukrainian].

9. Novakovskyi L.la., Kanash O.P., Leonets V.O. (2002). Konservatsiia dehradovanykh i maloproduktyvnykh ornykh zemel Ukrainy. [Conservation of degraded and unproductive arable land of Ukraine]. Visnyk ahrarnoi nauky. No 5. P. 5-10. [In Ukrainian].

10. Kaminskyi V.F., Shevchenko I.P. (2013). Dosvid orhanizatsii ta efektyvnoho vykorystannia zemelnykh uhid $v$ eroziino-nebezpechnykh ahrolandshaftakh zony Lisostepu. [Experience of organization and effective use of land in erosion-dangerous agrolandscapes of the forest-steppe zone]. Posibnyk ukrainskoho khliboroba. T. 1. Kyiv. P. 10-11. [In Ukrainian].

11. Kaminskyi V.F., Shevchenko I.P., Kolomiiets L.P. (2016). Teoretyko-metodolohichne zabezpechennia optymizatsii zemlekorystuvan silskykh terytorii $v$ konteksti realizatsii yevrointehratsiinoi polityky: naukovyi suprovid ta efektyvnist vprovadzhennia. [Theoretical and methodological provision of optimization of land use of rural areas in the context of the implementation of the European integration policy: scientific support and implementation efficiency]. Zemlerobstvo. No 2. [In Ukrainian].

12. Kaminskyi V.F., Shevchenko I.P., Kolomiiets I.P. (2016). Naukovo-metodychni zasady upravlinnia zemelnymy resursamy za adaptyvnoho zemlevporiadkuvannia. [Scientific and methodological principles of land resources management for adaptive land management]. Zemlerobstvo. No 1 (90). P. 3-9. [In Ukrainian].

13. Kaminskyi V.F., Shevchenko I.P., Kolomiiets L.P. (2017). Zemlevporiadne zabezpechennia okhorony i ratsionalnoho vykorystannia zemel silskohospodarskykh zemlekorystuvan. [Land management of the protection and rational use of agricultural land land use. Agriculture]. Zemlerobstvo. No 2. [In Ukrainian].

14. Shevchenko I.P., Kolomiets L.P. (2014). Optimization of rural land use in the requirements of European integration. Zemlerobstvo. No 1 - 2. P. 6-7. 